\title{
Intracellular germination of spores of Nosema apis Z
}

\author{
I Fries ${ }^{1 *}$, RR Granados 2, RA Morse 1 \\ 1 Cornell University, Entomology Department, Ithaca, NY 14853; \\ 2 Cornell University, Boyce Thompson Institute for Plant Research, Ithaca, NY 14853, USA
}

(Received 24 May 1991; accepted 18 October 1991)

\begin{abstract}
Summary - Intracellular germination of Nosema apis spores is shown in TEM preparations of infected honey bee (Apis mellifera) ventricular cells. A series of observations at different times postinfection provides support for a hypothesis that could explain the rapid intercellular spread of the parasite. It is suggested that the first spores produced often germinate and spread the parasite within the epithelium, whereas intact and durable spores are produced later in infected cells when they become more crowded with parasites.
\end{abstract}

Nosema apis / germination / spread / parasite

\section{INTRODUCTION}

Nosema apis $\mathrm{Z}$ is a spore-forming intracellular parasite of the honey bee (Apis mellifera $L$ ) that infects the ventricular cells. The spores are ingested with food and germinate after they have reached the ventricular lumen (Bailey, 1955). Like all microsporidia, $N$ apis injects its sporoplasm into the host cell and completes its developmental cycle intracellularly (Larsson, 1986).

If the temperature is optimal for the parasite, $+30-35{ }^{\circ} \mathrm{C}$ (Lotmar, 1943), the whole ventriculus becomes infected within 2 weeks post-infection (pi), irrespective of initial spore dose. This is due to autoinfection (Fries, 1988a). As infected ventricular cells are shed into the gut lumen, newly formed spores are released and germinate, thus spreading the infection to other parts of the gut (Bailey, 1981). However, the rapid spread of the parasite throughout the ventricular epithelium makes intercellular spread inevitable (Fries, 1989).

Intercellular spread by vegetative stages in the Nosematidae family has been indicated in in vitro studies (Ishihara, 1969; Kurtti et al, 1983; Kawarabata and Ishihara, 1984). Based on observations on in vivo infections, Fries (1988b; 1989) suggested that spores of $N$ apis germinate while still inside the cell where they were produced, and possibly inject the sporoplasm into adjacent cells through the extruded polar filament. The hypothesis of

\footnotetext{
* Present address : Bee Division, Swedish University of Agricultural Sciences, Box 7024, S-750 07 Uppsala, Sweden.
} 
intercellular spread between cells through germinating spores is supported by in vitro (Iwano and Ishihara, 1989, 1991), as well as in vivo (Avery and Anthony, 1983) observations in other Nosema species. Intracellular germination of spores has been observed in several other Nosema species (Lom, 1972; Larsson, 1981; Toguebaye and Marchand, 1984).

The completion of the developmental cycle of $N$ apis from ingestion of spores to production of new spores has been reported to be completed in 2 days (Kelliner, 1980 ), or 3-5 days (Bailey, 1981) if the temperature is optimal. Fries (1989) using low inoculation doses, found immature, mature, and emptied spores in the host cytoplasm 4 days pi. With a heavy inoculum, however, mature spores are observed more quickly than when low doses are used (Fries, 1988a).

This paper reports observations on the early infection and possible spread of $N$ apis in the ventricular epithelium of the honey bee using a heavy inoculum.

\section{MATERIALS AND METHODS}

Twelve h after a comb containing mature worker pupae was put in an incubator $\left(+34^{\circ} \mathrm{C}\right)$, newly emerged bees were collected. The bees were kept in the incubator at $+32^{\circ} \mathrm{C}$ in cages similar to those described by Kulincevic et al (1973) and supplied with sucrose in water solution 1/1 $(w / w)$ and freshly collected bee pollen ad lib. When the bees were 1 week old, they were starved for $2 \mathrm{~h}$ and then 50 bees were individually fed approximately $10^{6}$ spores per bee in 10$\mu l$ sucrose solution using a micropipette. The infected bees were placed in a cage at $+32{ }^{\circ} \mathrm{C}$ and supplied with sugar solution.

Spores for the inoculation were collected from live heavily infected bees after dissection of the intestinal tracts as described by Verbeke et al (1984) and homogenization in tap water. After purification of the spores according to the method of Cole (1970), hemacytometer counts similar to Cantwell (1970) were used to estimate the spore numbers.

Two bees were collected 2, 12, 24, 36 and $84 \mathrm{~h}$ pi. The ventriculus of each collected bee was removed and prefixed in $4 \%$ glutaraldehyde $(\mathrm{v} / \mathrm{v})$ in $0.067 \mathrm{M}$ sodium cacodylate buffer, $\mathrm{pH}$ 7.2 for 2 weeks. After prefixation, each ventriculus was cut transversely. The specimens were postfixed for $2 \mathrm{~h}$ in $2 \% \mathrm{OsO}_{4}(\mathrm{w} / \mathrm{v})$ in $0.1 \mathrm{MS}$ colloidine buffer and then dehydrated in an ascending series of ethanols, followed by propylene oxide. The specimens were embedded in epoxy resin (Agar 100) using routine procedures for electron microscopy.

After making light microscopic examination of rough sections, contrast colored with toluidine, thin sections from different parts of the specimens were mounted on copper grids. The thin sections were stained with uranyle acetate, followed by lead citrate, and then examined in a Zeiss EM 10 electron microscope at an accelerating voltage of $60 \mathrm{kV}$.

\section{RESULTS}

At 2 h pi no infected host cells could be detected. Intact as well as emptied spores could be found in the ventricular lumen. At $12 \mathrm{~h}$ pi, a few isolated parasite cells were detected in the posterior parts of the ventriculus (fig 1), but they could not be distinguished from later stages during merogony, in size or by any other character. No cytokinesis was seen at this stage, but spindle plaque and polar vesicles were visible, indicating nuclear division activities (fig 1). Cytokinesis occurred within $24 \mathrm{~h} \mathrm{pi}$ (fig 2) as diplokaryotic merozoites were budded off from multinucleate meronts (fig 2). At $36 \mathrm{~h}$ pi, immature spores as well as structures interpreted as emptied spores were found in the host cytoplasm (fig 3), along with other developmental stages. Also, it could be seen that the process of nuclear division in the daughter cells seemed to start before the completion of cytokinesis, where merozoites were budded off from multinucleate meronts (fig 4). 

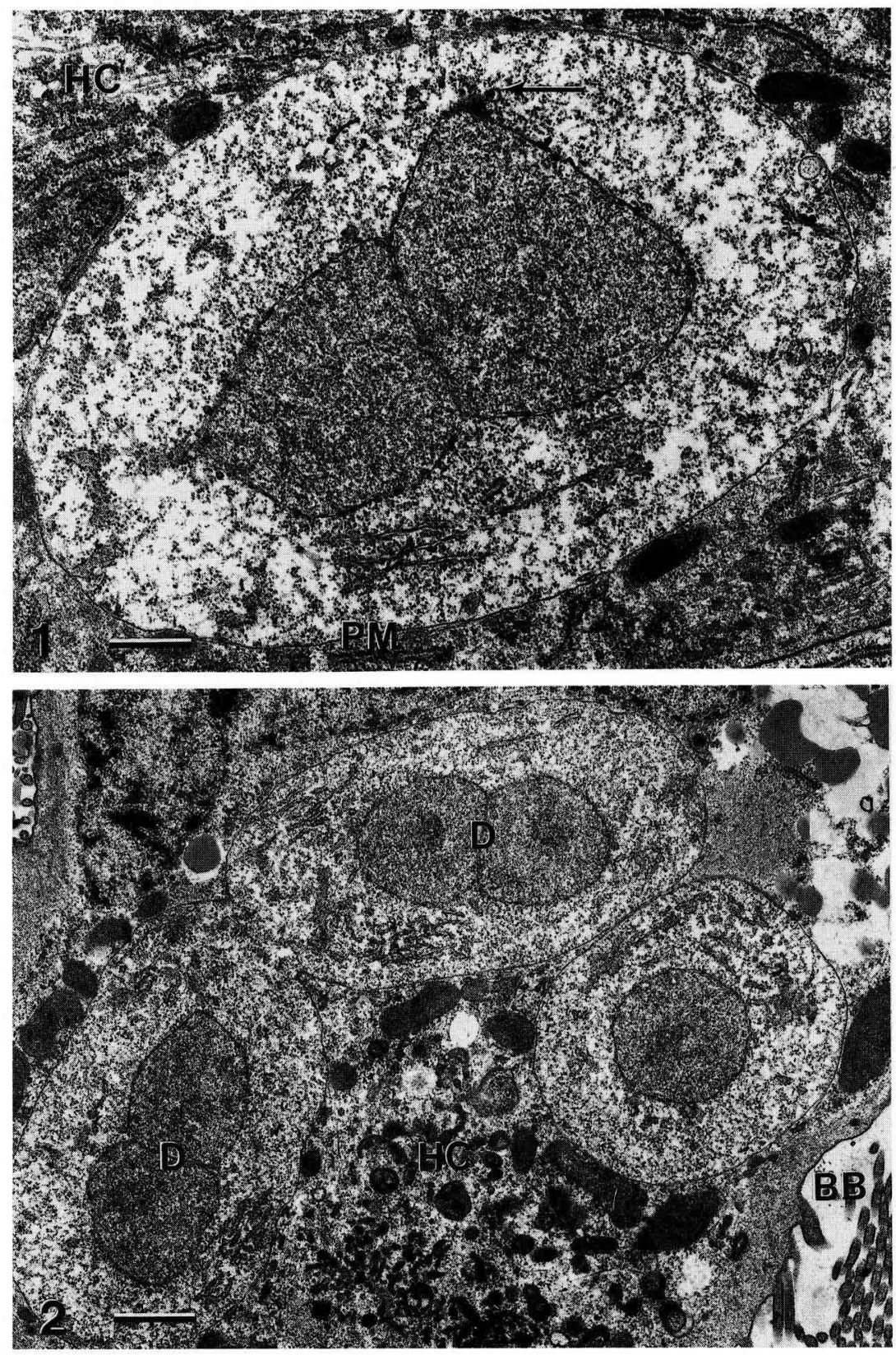

Fig 1. Meront in host cytoplasm (HC) $12 \mathrm{~h}$ pi. Note polar vesicle above spindle plaque (arrow) indicating nuclear division. Plasma membrane (PM). Bar $=0.5 \mu \mathrm{m}$.

Fig 2. Multinucleate meront with diplokarya (D) $24 \mathrm{~h}$ pi. Host cytoplasm (HC), Brush border (BB). $\mathrm{Bar}=1 \mu \mathrm{m}$. 

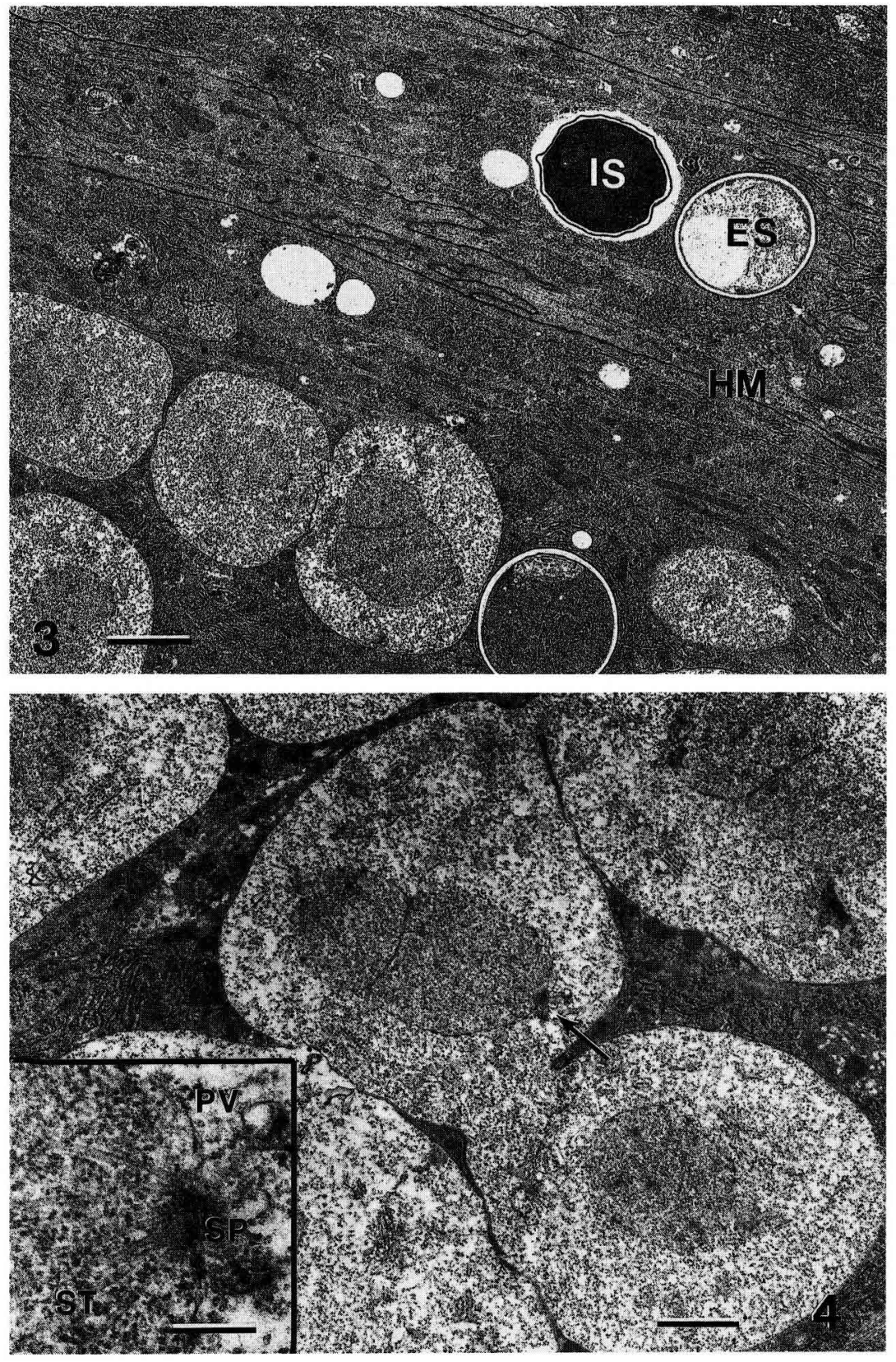

Fig 3. Immature spore (IS) and empty spore (ES) in host cytoplasm $36 \mathrm{~h}$ pi. Bar $=2 \mu \mathrm{m}$.

Fig 4. Multinucleate meront budding off diplokaryotic merozoites $36 \mathrm{~h}$ pi. Arrow indicates area enlarged in inset. $B a r=1 \mu \mathrm{m}$. Inset shows spindle plaque (SP), polar vesicle (PV) and spindle tubules (ST) in nucleus preparing for division. Bar $=0.25 \mu \mathrm{m}$. 
The nuclear divisions of the meronts were completed inside the nuclear membrane in a closed intranuclear pleuromitosis (Raikov, 1982) with the spindle tubes arranged in the plane of connection between diplokaryotic nuclei (fig 5). Structures that undoubtedly represent intracellular spore germination, when compared to intracellular germination in other Nosema species (Lom, 1972; Larsson, 1981; Toguebaye and Marchand, 1984), were seen $84 \mathrm{~h}$ pi (fig 6). The first intact spores were seen $84 \mathrm{~h}$ pi.

\section{DISCUSSION}

Prior to this investigation, the earliest stages of $N$ apis ultrastructurally described were collected $24 \mathrm{~h}$ pi (Fries, 1989). No newly injected sporoplasm was detected in this study; the youngest parasite cells found were seen $12 \mathrm{~h}$ after feeding bees with spores. These cells could not be distinguished from later stages in merogony and possible differences between cells in the first and second merogony are still based on observations under the light microscope (Gray et al, 1969).

At $36 \mathrm{~h}$ pi both immature spores and structures interpreted as emptied spores were found, along with vegetative stages, but no mature spores were seen. It has been shown that germination of Nosema $s p$ spores immediately after their formation inside host cells does occur in cell cultures (Iwano and Ishihara, 1989). With the presented observations, this indicates that $N$ apis is capable of completing the developmental cycle within $36 \mathrm{~h}$. Furthermore, it suggests that spores produced in host cells not already filled with parasites might germinate and release the sporoplasm in the same or in adjacent cells. This could explain the quick spread of the parasite throughout the epithelium once the para- site becomes established (Fries, 1988a). Evidence suggesting intracellular germination in $N$ apis development is demonstrated in the presented material (fig 6). The structural similarities between figure 6 and structures interpreted as emptied spores at $36 \mathrm{~h}$ pi (fig 3), support the hypothesis that the first spores produced germinate and possibly spread the parasite within the epithelium. Avery and Anthony (1983) have likewise reported intracellular germination and suggested intercellular spread in $N$ algerae infecting Anopheles albimanus. Recently, dimorphism of spores of Nosema spp in cultured cells was reported, where the first spores with thin endospores germinated spontanously (Iwano and Ishihara, 1991). The appearance of the endospore of emptied spores of $N$ apis reported earlier (Fries, 1989) as well as in this paper, is congruent with the observations of dimorphic spore development and intracellular germination of the first spores produced. This aspect needs further investigation in $N$ apis.

In this paper, intercellular spread of parasites is suggested to result from spores germinating inside host cells. However, transmission between microsporidian cells by vegetative stages, as suggested by several authors (Ishihara and Sohi, 1966; Tsang et al, 1982; Kurtti et al, 1983; Hayasaka and Kawarabata, 1990) is still a possibility. If they exist, the infective forms have yet to be isolated and identified.

Maddox (1968) suggested that spore production in Vairimorpha necatrix, infecting Pseudaletia uni-puncta, is a density dependent process where a certain population density of the vegetative forms must be reached before spores are produced. The observations presented in this study suggest that spores of $N$ apis in A mellifera can be produced within $36 \mathrm{~h}$ pi, before large numbers of vegetative stages accumulate in the host cells, and that in the ear- 

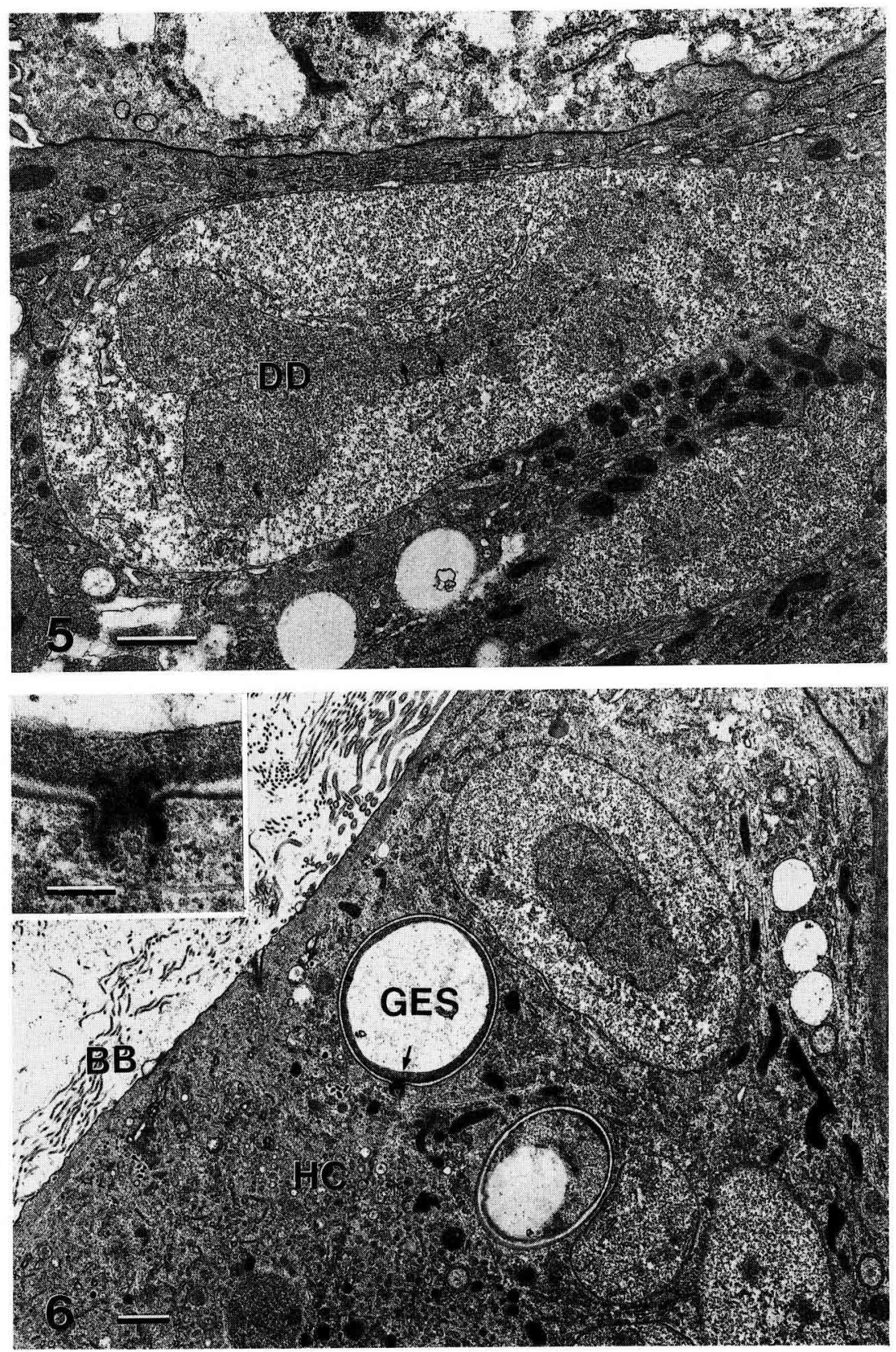

Fig 5. Dividing diplokaryon (DD) with spindle tubules (arrows) arranged in the plane of connection between the nuclei. Bar $=1 \mu \mathrm{m}$.

Fig 6. Germinated empty spore (GES) inside host cytoplasm (HC). Brush border (BB). Arrow indicates where inset was taken. $\mathrm{Bar}=1 \mu \mathrm{m}$. Inset shows detail of attachment site for ejected polar filament. Bar $=0.25 \mu \mathrm{m}$. 
ly stages of disease development, newly produced spores often germinate shortly after being produced. Possibly, intact spores are first found only once the host cells become more crowded with parasites. This would be contrary to the hypothesis of Maddox (1968) for $N$ necatrix, where spore formation is suggested to be triggered by increased parasite density. In $N$ apis it seems as if the first spores produced often germinate and possibly spread the parasite within or between cells, and the spores produced later, when the parasite density is greater, might remain intact in the host cytoplasm.

This study demonstrates the rapid division of the parasite in its early development. It is clear that preparation for nuclear divisions in the subsequent daughter cells are already taking place in multinucleate meronts before cytokinesis is completed to produce merozoites.

\section{ACKNOWLEDGMENTS}

The comments and suggestions on the manuscript by R Larsson, T Seeley and S Camazine are highly appreciated. This study was made possible through a grant from the SwedenAmerica Foundation.

\section{Résumé - Germination intracellulaire des spores de Nosema apis Z. Nosema} apis $Z$ est un parasite intracellulaire sporulant de l'abeille (Apis mellifera L) qui envahit les cellules du ventricule (intestin). Comme toutes les microsporidies, $N$ apis injecte son protoplasme dans la cellule hôte et accomplit son cycle de développement à l'intérieur de la cellule (Larsson, 1986). La propagation des stades végétatifs entre les cellules dans la famille des Nosematidae a été montrée par des études in vitro (Ishihara, 1969; Kurtti et al, 1983; Kabawarata et Ishihara, 1984). Fries (1988b, 1989) a suggéré que les spores de $N$ apis pouvaient germer lorsqu'elles étaient encore à l'intérieur de la cellule où elles avaient été produites et qu'elles pouvaient injecter le sporoplasme dans les cellules adjacentes. Ce travail relate les observations faites sur l'infection précoce et la propagation éventuelle de $N$ apis dans l'épithélium du ventricule de l'abeille.

Des abeilles âgées d' 1 sem ont reçu chacune, à l'aide d'une micropipette, $10 \mu$ l de solution de saccharose renfermant environ $10^{6}$ spores. Les abeilles infectées ont été maintenues en cages à $32^{\circ} \mathrm{C}$ et approvisionnées avec du sirop. Deux abeilles ont été prélevées toutes les $2,12,24,36$ et $84 \mathrm{~h}$. Le ventricule de chaque abeille était enlevé et préfixé dans $4 \%$ de glutaraldéhyde ( $\mathrm{v} / \mathrm{v}$ ) dans un tampon de cacodylate de sodium à $0,067 \mathrm{M}, \mathrm{pH} \mathrm{7,2}$ pendant 2 sem. Le ventricule était ensuite coupé transversalement, postfixé, déshydraté et inclus dans de la résine époxy (Agar 100) pour être étudié en microscopie électronique.

Résultats : $12 \mathrm{~h}$ après l'infection (pi), quelques ceilules isolées du parasite ont été décelées dans les parties postérieures du ventricule (fig 1), mais on ne pouvait les distinguer des stades ultérieurs de la mérogonie, ni en taille ni par d'autres caractères (fig 1). La cytokinèse s'est produite $24 \mathrm{~h}$ pi, lorsque les mérozoïtes diplocaryotes ont bourgeonné à partir des mérontes multinucléaires (fig 2). À trente-six h pi, on a trouvé dans le cytoplasme de l'hôte des spores immatures et des structures considérées comme des spores vidées (fig 3), mais aucune spore mature. Des structures qui correspondaient sans aucun doute à la germination intracellulaire des spores ont été repérées 84 h pi (fig 6).

Discussion : cette étude n'a décelé aucun sporoplasme fraîchement injecté. Iwano et Ishihara (1989) ont montré dans des cultures de cellules que la germination des spores de $N$ apis avait lieu juste après leur formation dans les cellules de l'hôte. 
Le travail présent montre que $N$ apis est capable d'accomplir son cycle de développement en $36 \mathrm{~h}$. II suggère en outre que les premières spores produites dans les cellules hôtes, non encore remplies de parasites, peuvent germer et libérer leur sporoplasme dans la même cellule ou dans les cellules adjacentes. Ceci pourrait expliquer la propagation rapide du parasite à travers l'épithelium, dès qu'il est installé (Fries, 1988a). II se multiplie rapidement lors de la première phase de développement. Les divisions nucléaires dans les cellules filles sont préparées dans les mérontes muitinucléaires avant que la cytokinèse ne soit achevée.

\section{Nosema apis / germination / propaga- tion / parasite}

\section{Zusammenfassung - Intracelluläre Keimung der Sporen von Nosema apis.} Nosema apis Z ist ein sporenbildender intrazellulärer Parasit der Honigbiene (Apis mellifera $L$ ), der die Darmzellen befällt. Wie alle Mikrosporidien injiziert $N$ apis sein Sporoplasma in die Wirtszelle und vollendet seinen Entwicklungszyklus intrazellulär (Larsson, 1986). Die Ausbreitung der vegetativen Stadien zwischen den Zellen wurde in der Familie der Nosematiden durch in vitro Untersuchungen von Ishihara, 1969, Kurtti et al, 1983 und Kawarabata und Ishihara, 1984 gezeigt. Fries (1988b, 1989) vermutet, daß die Sporen von $N$ apis schon innerhalb der Zellen keimen, in denen sie erzeugt wurden, und daß sie möglicherweise inr Sporoplasma in benachbarte Zellen injizieren. Die Arbeit berichtet über Beobachtungen an frühen Infektionsstadien und die mögliche Ausbreitung von $N$ apis im Mitteldarmepithel der Honigbiene. Honigbienen im Alter von einer Woche wurden mittels einer Mikropipette pro Biene ungefähr $10^{6}$ Sporen in 10 $\mu \mathrm{l}$ Zuckerlösung gefüttert. Die infizierten
Bienen wurden in Käfigen bei $32{ }^{\circ} \mathrm{C}$ gehalten und mit Zuckerlösung versorgt. Jeweils $2,12,24,36$ und 84 Stunden nach der Infektion wurden je zwei Bienen entnommen. Der Mitteldarm jeder Biene wurde dann herauspräpariert und in 4\% Glutaraldehyd $(\mathrm{v} / \mathrm{v})$ in $0.067 \mathrm{M}$ Natriumcacodylat-Puffer, $\mathrm{pH} 7.2$, für zwei Wochen vorfixiert. Nach der Vorfixierung wurde jeder Mitteldarm transversal geschnitten. Nach Nachfixierung und Entwässerung wurden die Objekte in Epoxyharz (Agar 100) eingebettet, wobei die Routineverfahren der Elektronen-Mikroskopie benutzt wurden. Zwölf Stunden nach der Infektion wurden einige wenige isolierte Parasitenzellen im hinteren Teil des Mitteldarms entdeckt (Abb 1), aber es war nicht möglich, sie aufgrund ihrer Größe oder irgendeines anderen Merkmals von späteren Stadien der Merogonie zu unterscheiden (Abb 1). Die Cytokinese erfolgt innerhalb von 24 Stunden pi, wenn sich zweikernige Merozoiten durch Knospung von den vielkernigen Meronten abtrennten (Abb 2). Bei 36 Stunden wurden im Gastcytoplasma unreife Sporen und auserdem Strukturen gefunden, die als entleerte Sporen interpretiert werden können (Abb 3) jedoch keine reifen Sporen. Strukturen, die zweifellos als intrazelluläre Sporenkeimung $\mathrm{zu}$ betrachten sind, wurden 84 Stunden nach Infektion gefunden (Abb 6). In dieser Untersuchung wurde kein frisch injiziertes Sporoplasma gefunden. Es ist früher gezeigt worden, daß die Keimung von Nosema sp-Sporen in Zellkulturen unmittelbar nach ihrer Bildung in der Wirtszelle erfolgt (Iwano und Ishihara, 1989). Zusammen mit den vorliegenden Beobachtungen weist dies darauf hin, daß $N$ apis in der Lage ist, den Entwicklungszyklus innerhalb von 36 Stunden $z u$ vollenden. Außerdem lassen sie vermuten, daß die ersten Sporen, die in einer noch nicht mit Parasiten gefülten Wirtszelle erzeugt werden, in derselben Zelle keimen und die Sporoplasten in derselben 
oder in benachbarten Zellen freisetzen könnten. Dies könnte die rasche Ausbreitung des Parasiten in dem Epithelium erklären, sobald sich der Parasit festgesetzt hat (Fries, 1988a). Diese Untersuchung zeigt die rasche Teilung des Parasiten während seiner frühen Entwicklungsphase. Die Vorbereitung zu Kernteilungen in den folgenden Tochterzellen erfolgt in den vielkernigen Meronten zur Erzeugung von Merozoiten, noch bevor die Cytokinese abgeschlossen ist.

\section{Nosema apis / Keimung / Ausbreitung / Parasit}

\section{REFERENCES}

Avery SW, Anthony DW (1983) Ultrastructural study of early development of Nosema algerae in Anopheles albimanus. $J$ Invertebr Pathol 42, 87-95

Bailey $L$ (1955) The infection of the ventriculus of the adult honey bee by Nosema apis $Z$. Parasitology 45, 86-94

Bailey L (1981) Honey Bee Pathology. Academic Press, London

Cantwell GE (1970) Standard methods for counting Nosema spores. Am Bee J 110, 222-223

Cole RJ (1970) The application of the "triangulation" method to the purification of Nosema spores from insect tissue. J Invertebr Pathol 15, 193-195

Fries I (1988a) Infectivity and multiplication of Nosema apis $Z$ in the ventriculus of the honey bee (Apis mellifera L). Apidologie 19, 319328

Fries I (1988b) Contribution to the study of Nosema disease (Nosema apis Z) in honey bee (Apis mellifera L), colonies. Ph D Thesis, Swedish University of Agricultural Science, Uppsala, Sweden

Fries I (1989) Observations on the development and transmission of Nosema apis $Z$ in the ventriculus of the honey bee. J Apic Res 28, 107-117
Gray FH, Cali A, Briggs JD (1969) Intracellular stages in the life cycle of the microsporidian Nosema apis. J Invertebr Pathol 14, 391-394

Hayasaka S, Kawarabata T (1990) Cloning of microsporidian Nosema bombycis (Microsporida: Nosematidae) in insect cell cultures by a limiting dilution method. $J$ invertebr Pathol 55, 35-40

Ishihara R (1969) The life cycle of Nosema bombycis as revealed in tissue culture cells of Bombyx mori. J Invertebr Pathol 14, 316-320

Ishihara R, Sohi SS (1966) Infection of ovarian tissue culture of Bombyx mori by Nosema bombycis spores. J Invertebr Pathol 8, 538540

Iwano H, Ishihara R (1989) Intracellular germination of spores of Nosema sp immediately after their formation in cultured cells. $J$ Invertebr Pathol 54, 125-127

Iwano H, Ishihara R (1991) Dimorphism of Nosema spp in cultured cells. $J$ Invertebr Pathol $57,211-219$

Kawarabata T, Ishihara R (1984) Infection and development of Nosema bombycis (Microsporida: Protozoa) in a cell line of Antheraea eucalypti. J Invertebr Pathol 44, 52-62

Kellner N (1980) Studie van de levenscyclus van Nosema apis Zander in de honingbij (Apis mellifera L). Dissertation, Fac Wetenschappen, Rijksuniversitet Gent, Belgium

Kulincevic JM, Rothenbuler WC, Stairs GR (1973) The effect of presence of a queen upon outbreak of a hairless-black syndrome in honey bee. J Invertebr Pathol 21, 241-247

Kurtti JT, Tsang RK, Brooks MA (1983) The spread of infection by the microsporidian Nosema disstriae, in insect cell lines. J Protozoo/ 30, 652-657

Larsson R (1981) Description of Nosema tractabile $\mathrm{n} \mathrm{sp}$ (Microspora, Nosematidae), a parasite of the leech Helobdella stagnalis (L) (Hirudinea, Glossiphoniidae). Protistologica 17, 407-422

Larsson R (1986) Ultrastructure, function, and classification of Microsporidia. Progr Protistol 1, 325-390

Lom $J$ (1972) On the structure of the extruded microsporidian polar filament. $Z$ Parasitenkd $38,200-213$ 
Lotmar R (1943) Über den Einfluss der Temperatur auf den Parasiten Nosema apis. Beih Schweiz Bienenztg 1, 261-284

Maddox JV (1968) Generation time of the microsporidian Nosema necatrix in the larvae of the army worm, Pseudaletia unipuncta. $J$ Invertebr Pathol 11, 90-96

Raikov IB (1982) The Protozoan Nucleus. Springer-Verlag, Vienna

Toguebaye BS, Marchand B (1984) Étude ultrastructurale de stades de développement et de la mitose sporogonie de Nosema henosepilachnae n sp (Microsporidia, Nosemati- dae) parasite de Henosepilachna elaterii (Rossi, 1794) (Coleoptera, Coccinellidae). Prostitologica 20, 165-179

Tsang KR, Brooks MA, Kurtti TJ (1982) Culture conditions regulating the infection of cells by an intercellular organism. In: Invertebrate Cell Culture Applications (Maramorosch K, Mitsuhashi J, eds) Academic Press, New York, 125-157

Verbeke M, Jacobs FJ, de Rycke PH (1984) Passage of various particles through the ventriculus in the honey bee (Apis mellifera $\mathrm{L}$ ). Am Bee J 123, 468-470 